\title{
Analysis of Determinants of Split Ratings and Rating Conservativeness between Japanese and US Credit Rating Agencies
}

\author{
Yoshiki Shimizu (Corresponding author) \\ Kwansei Gakuin University, Japan \\ Email: yshimizu48@gmail.com \\ Junghee Lee \\ Kwansei Gakuin University, Japan
}

Hideki Takei

Central Washington University, USA

Received: April 9, 2013 Accepted: April 20, $2013 \quad$ DOI: 10.5296/ijafr.v3i1.3507

\begin{abstract}
In the previous paper, we confirmed the existence of the split ratings between Japanese and US credit rating agencies (CRAs). Our study did not support early studies suggesting that the split ratings were merely random occurrences. Rather, our findings suggested that the split ratings occurring between Japanese and US CRAs were not random and frequently occurring. The Japanese CRA assigned less conservative ratings than the US CRAS. In this paper, we performed the multivariate regression analysis to find variables which would differentiate the degree of rating conservativeness. Our samples were 192 Japanese companies which were assigned their ratings by Japanese and US credit rating agencies. We used 10-year bond ratings of these companies from 2000 to 2009. Our data sources were Nikkei NEEDS-Financial Quest for Japanese ratings and financial information and Thomson Reuters Datastream for US ratings. All Financial Data of the 192 companies were collected from Nikkei NEEDS-Financial Quest. According to our findings, Japanese agency seems to put higher weight on ROA than US agencies while all agencies seem to use variables such as asset, liquidity, and leverage to assign ratings. We assume that this is the main variable that has differentiated the degree of rating conservativeness.
\end{abstract}

Keywords: Split Ratings, Bond Ratings, ROA, Japan, USA 


\section{MlMacrothink}

International Journal of Accounting and Financial Reporting

ISSN 2162-3082

2013, Vol. 3, No. 1

\section{Introduction}

The integrity of credit rating systems has been discussed after "the Lehman Shock" that was caused by operational failure of the Lehman Brothers in 2008 and the financial crisis in Europe. Such discussions are becoming more intense after the A.I.G. Financial Products' reckless speculation caused operational failure of its parent company, American International Group Inc. (AIG) with the highest credit rating, in 2008.

The integrity discussions motivated researchers to assess the process which major credit rating agencies (CRAs) have used for their credit rating decision including the technical standards, the ability to obtain information, and other factors presumed to be used by CRAs. When two different rating agencies give two different ratings for a company, split rating will exist. Since investors find two different ratings for a company, split rating will negatively influence effectiveness of investment decisions.

The two representing credit ratings agencies in the United States are Standard and Poors (S\&P) and Moody's which issue credit ratings not only on the corporate bonds but also the sovereign bonds. A large number of companies and nations outside the United States also prefer to have their bonds rated by these CRAs for higher level of assurance matter. In addition to such preference, the globalization of investment has encouraged the CRAs to expand their business to various local markets. For example, in Japan, Japanese corporate bonds often have multiple ratings issued by S\&P, Moody's, and Japanese domestic CRAs that are not affiliated with those major global agencies.

In general, CRAs obtain the financial information from the bond-issuer's annual report. Therefore, investors usually assume ratings of both US and local CRAs have same ratings because the ratings are made based on identical financial information. Of course, if the technical standard that individual CRA employs in the rating process is only based on the disclosed financial information, there should not be significant difference in ratings among CRAs. Therefore, the existence of split ratings implies that there must be something other than the public information per se that influences the credit decision.

Since we confirmed the existence of the split ratings between Japanese and US credit rating agencies (CRAs) in the previous research. This time, our research goal is to examine if there are variables which may cause the split ratings.

\section{Literature Review}

Credit ratings mean bond issuers' trustworthiness. Therefore, the ratings affect interest rates on corporate bonds. Since the ratings show trustworthiness, better ratings mean better financial conditions of companies.

Investors will worry about debt obligations of companies with poor ratings while they will be comfortable to buy bonds of companies with high ratings. Investors will determine corporate 
bonds as "investment grade" or "speculative grade" based on the bond ratings regulation (Adams et al. 1999). According to Cantor (2007), US fund managers prefer bonds with multiple ratings to bonds with single rating. In addition, their preference to higher rating bonds is regardless of trustworthy of the rating while Europeans prefer relatively conservative ratings.

Recently, as globalization of financial markets and transactions continue, investors and regulators start being more skeptical about the integrity in bond ratings process. Their main concern is if credit ratings issued by the large major CRAs are actually trustworthy. This concern is getting more serious after the European financial crisis which started from the collapse in Greek sovereign bonds. The split rating is considered as one of the signs of poor trustworthy of the major CRAs (Cantor, 2007).

Researchers have tried to find evidences of the split ratings. According to Ederington (1986), approximately 13 percent of corporate bonds had split ratings during the 1975-1980 periods. Ederington pointed out that the occurrence of split ratings was more likely random because there was not significant discrepancy in the technical standards or rating criteria used by the major CRAs.

According to Dale and Thomas (1991), governmental regulatory bodies such as Basle II or European Capital Adequacy Directive started asking CRAs to apply strict rating methods to eliminate split ratings after the US subprime mortgage crisis. They believed the elimination of split ratings would protect investors.

Canter (2007) concluded that split ratings had become a common phenomenon. Livingston (2010) supported the conclusion of Canter (2007) and showed that Moody's was more likely to assign conservative ratings than S\&P. This was because the Moody's ratings incorporate not only the probability of default but also the expected recovery rate while the S\&P rating reflects strictly a measure of default risk.

Livingston (2010) found not only the existence of split ratings but also behaviors of investors to deal with the split ratings. According to Livingston (2010), risk adverse investors were more likely to pick the bonds with Moody's than those rated aggressively by the S\&P. In other words, the risk adverse investors used the split ratings to measure risk of bonds.

\section{Research Questions}

Our research question is "What are the factors that may cause the split ratings between Japanese and US CRAs?"

This is an extension of the questions of the precious study. Since there are split ratings between Japanese and US CRAs, there should be influential factors which are causing the split ratings. 


\section{Macrothink}

\section{Our Samples}

Initially, we selected 4,969 publicly traded companies in Japanese stock markets between 2000 and 2009. Then, we used 192 companies which issued corporate bonds during the same period to see if there is the split ratings between Japanese and US CRAs. Needless to say, the bonds of 192 companies were rated by one Japanese and at least one of US CRAs. The Japanese CRA is Rating \&Investment Information, Inc. (R\&I) which is one of the major and most reliable Japanese CRAs. The US CRA is either S\&P or Moody's. Among the 192 samples, 96 bonds were rated by Moody's and R\&I while 58 bonds were rated by S\&P and R\&I. The remaining 38 bonds were rated by Moody's, S\&P, and R\&I. Through this approach, we could eliminate the spurious effect that might cause split ratings other than country-specific rating process. Our data sources were Nikkei NEEDS-Financial Quest for Japanese ratings and Thomson Reuters Datastream for US ratings. All financial data used in our regression model were collected from Nikkei NEEDS-Financial Quest.

\section{Method to Find Determinant of Split Ratings}

In order to find the factors, we developed the following regression model.

\section{Difference $=\beta_{0}+\beta_{1}$ ROA $+\beta_{2}$ ASSET $+\beta 3$ LEVERAGE $+\beta 4$ LIQUIDITY}

Where, Difference: Absolute value of Rating Difference, where Rating Difference calculated as Japanese CRA rating grade less US CRA rating grade.

ROA: Return on Asset measured as company's net profit divided by company's total asset.

ASSET: Natural logarithm of total asset.

LEVERAGE: Total liabilities divided by total equity.

LIQUIDITY: Current asset divided by current liability.

The dependent variable, Difference, denotes the difference between ratings by the Japanese and US CRAs. We defined the variable "Difference" as "Absolute value of Rating Difference, where Rating Difference calculated as Japanese CRA rating grade less US CRA rating grade.

The independent variables are standard financial indicators of liquidity, solvency, and profitability. Usually, these indicators are found to be associated with credit ratings. Table 1 summarizes statistics of the variables.

Table 2 shows the result of our multivariate regression model analysis. The coefficients of ASSET and ROA are positive and significant $(t$-value $=4.03 ; \mathrm{p}<1 \%$, and $t$-value $=4.79 ; \mathrm{p}<1 \%$, respectively). This means that Difference increases with either ASSET or ROA increases. Therefore, this shows that Japanese and US CRAs have different approach to ASSET and ROA in their rating decision making process. 
The coefficients of LEVERAGE and LIQUIDITY are significantly negative $(t$-value $=-2.04$; $\mathrm{p}<5 \%$, and $t$-value $=-3.83 ; \mathrm{p}<1 \%$, respectively). This indicates that Difference decreases as either LEVERAGE or LIQUIDITY increases. Therefore, this shows that the magnitude of split ratings between Japanese and US CRAs increases when they assign the credit ratings for a company with high credit risk.

Table 1: Summary of Statistics of Variables

\begin{tabular}{|c|c|c|c|c|c|c|}
\hline & \multirow{3}{*}{ Mean } & \multirow{3}{*}{ Std. Deviation } & \multicolumn{4}{|c|}{ Quantile } \\
\hline & & & $100 \%$ & $75 \%$ & $50 \%$ & $25 \%$ \\
\hline & & & & \multicolumn{3}{|c|}{ Median } \\
\hline Difference & 3.15202 & 2.05535 & 11 & 4 & 3 & 2 \\
\hline ROA & 0.13669 & 0.09118 & 0.37298 & 0.21271 & 0.1280266 & 0.0596942 \\
\hline ASSET & 14.8346 & 1.01103 & 16.4939 & 15.6773 & 14.8931 & 14.3264 \\
\hline LEVERAGE & 4.65122 & 2.18734 & 16.7 & 5.68 & 4.5 & 2.84 \\
\hline \multirow[t]{11}{*}{ LIQUIDITY } & 105.725 & 61.0483 & 553.99 & 129.74 & 110.11 & 69.25 \\
\hline & \multicolumn{6}{|c|}{ Pearson Correlation Coefficients } \\
\hline & & Asset & Leverage & Liquidity & Difference & \\
\hline & \multirow[t]{2}{*}{ ROA } & 0.1806 & 0.27908 & -0.41815 & 0.32349 & \\
\hline & & 0.0002 & $<.0001$ & $<.0001$ & $<.0001$ & \\
\hline & \multirow[t]{2}{*}{ ASSET } & & 0.37332 & -0.3266 & 0.26376 & \\
\hline & & & $<.0001$ & $<.0001$ & $<.0001$ & \\
\hline & \multirow[t]{2}{*}{ LEVERAGE } & & & -0.35553 & 0.1086 & \\
\hline & & & & $<.0001$ & 0.0262 & \\
\hline & \multirow[t]{2}{*}{ LIQUIDITY } & & & & -0.32666 & \\
\hline & & & & & $<.0001$ & \\
\hline
\end{tabular}

Table 2: Determinant of Split Ratings

\begin{tabular}{cccc} 
Difference $=\beta{ }_{0}+\beta{ }_{1}$ ROA $+\beta_{2}$ ASSET $+\beta_{3}$ LEVERAGE $+\beta{ }_{4}$ LIQUIDITY \\
\hline Variable & Coefficient & $t$ Value & $\operatorname{Pr}\rangle|\mathrm{t}|$ \\
Intercept & -2.37084 & -1.58 & 0.1146 \\
ROA & 5.33314 & 4.79 & $<.0001$ \\
ASSET & 0.40167 & 4.03 & $<.0001$ \\
LEVERAGE & -0.09597 & -2.04 & 0.0424 \\
LIQUIDITY & -0.00668 & -3.83 & 0.0001 \\
\hline
\end{tabular}




\section{$\Lambda$ Macrothink}

\section{Conclusion}

The lesser conservativeness of Japanese CRA may be because the Japanese CRA tends to put more weight on certain financial indicators. Our Multivariate Regression Model analysis showed the Japanese CRA might put more weight on ROA, ASSET, LEVERAGE, and LIQUIDITY. Especially, ROA is the strongest influential indicator.

\section{References}

Cantor, Richard, OwainapGwilym, and Stephen Thomas. (2007). The Use of Credit Ratings in Investment Management in the US and Europe. Working Paper as of Feb 16, 2007.

Ederington, Louis H. (1986). Why Split Ratings Occur. Financial Management, 15(1), 37-47.

Hernandez-Trillo, Fausto, Richardo Smith-Ramirez, EduadroCavallo, and Tito Cordella. (2009). Credit Ratings in the Presence of Bailout: The Case of Mexican Subnational Government Debt. Economia, 10(1), 45-79.

Kisgen, Darren J. (2006). Credit Ratings and Capital Structure. The Journal of Finance, .61(3), 1035-1072.

Livingston, Miles, Jie Wei, and Lei Zhou. (2010). Moody's and S\&P Ratings: Are They Equivalent? Conservative Ratings and Split Rated Bond Yields. Journal of Money, Credit and Banking (Forthcaming).

Moody's Investors Service, Inc. (2006). "Probability of Default Ratings and Loss Given Default Assessments for Non-Financial Speculative-Grade Corporate Obligors in the United States and Canada." Moody's Investors Service, Inc. Available at https://www3.nd.edu/ carecob/April\%202007\%20Conference/Loss\%20given\%20default\%2 Orating\%20methodology.pdf (March, 2013).

Moody's Investors Service, Inc. “Moody's Corporation.” Moody's Investors Service, Inc. Available at http://www.moodys.com/Pages/atc.aspx (March, 2013).

Odders, Elizabeth.R. (2006). Credit Ratings and Stock Liquidity. The Review of Financial Studies, 19(1), 119-157.

Rating and Investment Information, Inc. "Ratings." Rating and Investment Information, Inc. Available at http://www.r-i.co.jp/eng/ (March, 2013).

Reinhart, Carmen M. (2002). Default, Currency Crisis, and Sovereign Credit Ratings. The World Bank Economic Review, 10(2), 151-170. 
Standard \& Poor's Financial Services LLLC. "RATINGS." Standard \& Poor's Financial Services LLLC. Available at http://www.standardandpoors.com/ratings/en/ap/ (March, 2013).

\section{Copyright Disclaimer}

Copyright reserved by the author(s).

This article is an open-access article distributed under the terms and conditions of the Creative Commons Attribution license (http://creativecommons.org/licenses/by/3.0/). 